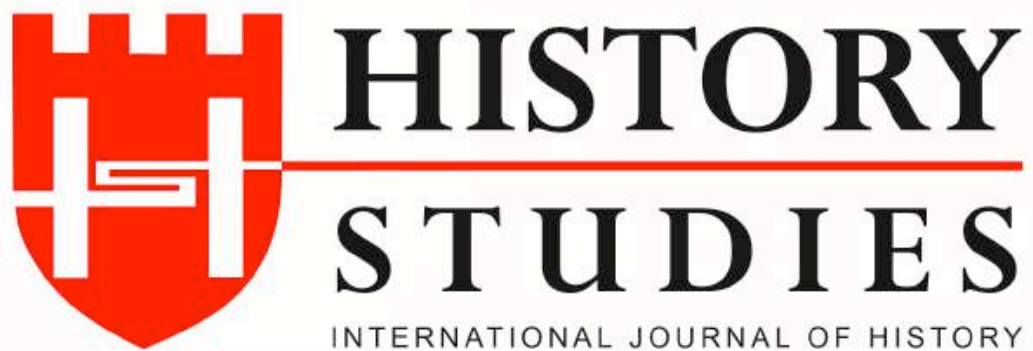

ISSN: 13094173 (Online) 1309 - 4688 (Print)

Volume 11 Issue 6, December 2019

DOI Number: 10.9737/hist.2019.793

Araştırma Makalesi

Makalenin Geliş Tarihi: 28.11.2019 Kabul Tarihi: 12.12.2019

Atıf Künyesi: Aydın Erön, “Akhisar, Karahöyük Dağı Çevresinde Yer Alan Mahallelerde Devşirme Mimari Malzeme Kullanımı Üzerine Düşünceler", History Studies, 11/6, Aralık 2019, s. 1925-1945.

\title{
AKHISAR, KARAHÖYÜK DAĞI ÇEVRESINDE YER ALAN MAHALLELERDE DEVŞIRME MIMARI MALZEME KULLANIMI ÜZERINE DÜŞÜNCELER
}

\section{Thoughts About The Usage of Spolia Architectural Material in Disctricts Located on The Outskirts of Mount Karahoyuk; Akhisar}

Dr. Aydun Erön

ORCID No: 0000-0003-1611-2296

Aydın Adnan Menderes Üniversitesi

Öz: Karahöyük Dağı, Manisa ili, Akhisar ilçe sınırları içerisinde yer almaktadır. Oldukça stratejik bir noktada yer alan dağın çevresi erken dönemlerden itibaren iskan için tercih edilmiştir. 2016-2018 yılları arasında ekibimiz tarafından söz konusu dağ ve çevresindeki yerleşimleri tespit etmek amacıyla bir yüzey araştırması çalışması gerçekleştirilmiştir. Çalışmalar sırasında dağın çevresinde yer alan eskiden "köy" günümüzde ise "mahalle" olarak adlandırılan yerleşimlere de gidilerek incelemelerde bulunulmuştur. Karahöyük Dağı'nın güneyinde Moralılar ve Rahmiye, batısında ise Kayalıŏlu mahalleleri bulunmaktadır. Söz konusu mahalleler içerisinde yapılan araştırmalarda devşirme malzeme olarak kullanılan çok sayıda mimari yapı parçası tespit edilmiştir. Mimari parçaların bir bölümü mahallelerin meydanlarına yakın alanlarda karşımıza çıkmaktadır. Mahalle meydanında yapılan çevre düzenlemeleri sırasında devşirme sütun gövdesi parçalarının bir düzen dahilinde alana yerleştirildiği anlaşılmaktadır. Ayrıca evlerin bahçe girişleri yanında da mimari yapı parçalarına rastlanılmıştır. Moralılar, Rahmiye ve Kayalıoğlu mahallelerinde bulunan eserlerin büyük çoğunluğunu sütun gövdesi ve profilsiz mimari yapı parçaları oluşturmaktadır. Sütun başlıkları ve kaideleri de devşirme malzeme olarak kullanılmıștır. Mimari yapı parçaları genel olarak Roma Dönemi örneklerini hatırlatmaktadır. Bezemesiz parçalar çoğunluktadır. Yapılan incelemeler sonucunda en çok mermer ve dasit malzemenin tercih edildiği anlaşılmıştır. Traverten ve kireçtaşından yapılmış az sayıda eser bulunmuştur. Yüzey araştırması çalışması sırasında tespit edilen mimari yapı parçalarının mahallelerin yakınlarında yer alan höyüklerden getirilmiş olma ihtimali oldukça yüksektir.

Anahtar Kelimeler: Akhisar, Karahöyük Dağı, Modern Yerleşimler, Mimari Malzeme, Devşirme.

Abstract: Mount Karahoyuk is located inside the province borders of Akhisar which is a town in the city of Manisa. From the early on; foothills of the mountain, which is a highly strategic spot, have been preferred for settlement. Between the years 2016 and 2018 a surface research has been conducted by our team in order to identify settlements on and around the mountain in question. During the survey, settlements which previously were "villages" but now "districts"; had been visited and explored. On the south of Mount Karahoyuk; Moralilar and Rahmiye districts are located and Kayalıglu district is on the west. Throughout the research done in the districts aforementioned, the existence of a wide range of pieces of architectural structures which included spolia material had been confirmed. A part of these architectural pieces appears on the district squares and near fields. It has been realized that spolia shaft pieces were positioned on the area in an orderly manner during landscaping. Besides, pieces of architectural structures had been encountered near the garden entries of the houses too. Most of the architectural works found in Moralilar, Rahmiye and Kayaloglu districts consists of columns and some pieces lacking profile. Both capitals and plinths are also used as spolia material. Architectural structure pieces remind the samples of Roman period in general. Plain pieces predominate. Results of the examination communicate that marble and dacite material had been preferred. There were also limited amount of travertine and limestone works. It is highly possible that the architectural pieces identified during the surface research had been brought from the nearby mounds.

Keywords: Akhisar, Mount Karahoyuk, Modern Settlements, Architectural Material, Spolia. 


\section{Giriş}

Karahöyük Dağı, Manisa ili, Akhisar ilçe sınırları içerisinde yer almaktadır (Fig. 1). $525 \mathrm{~m}$ yükssekliğindeki dağ, konumu nedeniyle oldukça stratejik bir noktada bulunmaktadır. Akhisar Ovası'nın ortasında yer alan yükseltinin kuzeyinden günümüzde Balıkesir-Manisa yolu, doğusundan ise Akhisar-Salihli yolu geçmektedir. Erken tarihlerden itibaren Karahöyük Dağı'nın çevresinin iskan için tercih edildiği tespit edilmiştir. Bu durum günümüz için de geçerlidir. Günümüzde dağın güneyinde Moralılar ve Rahmiye mahalleleri yer almaktadır. Batısında ise Kayalıŏlu Mahallesi bulunmaktadır.

Akhisar Ovası'nın ortasında yer alan Karahöyük Dağı ve çevresindeki erken dönem yerleşimleri ilk kez D. French tarafından tespit edilmiştir. French, Balıkesir ve Manisa illerini kapsayan yüzey araştırması çalışmaları sırasında Karahöyük Dăğ'nın çevresindeki erken dönem yerleşimlerini de incelemiştir ${ }^{1}$. Kulaksızlar Mermer Atölyesi çevresinde yüzey araştırması çalışmaları yapan R. Dinç, çalışmasının ikinci yılında Karahöyük Dağı'nın çevresindeki yerleşimlerde de çalışmalar gerçekleştirmiştir ${ }^{2}$. E. Akdeniz, Manisa ve çevresinin Prehistorik-Protohistorik çağlardaki iskanı konusunda gerçekleştirdiği yüzey araştırmaları sırasında Karahöyük Dağı ve çevresindeki erken dönem yerleşimlerini ayrıntılı olarak incelemiştir ${ }^{3}$. Söz konusu çalışmaların yanı sıra Karahöyük Dağı çevresinin arkeolojisi açısından C. Roosevelt ${ }^{4}$ ve T. Takaoğlu ${ }^{5}$ 'nun çalışmaları da oldukça önemlidir.

Konumu nedeniyle oldukça önemli olduğunu düşündüğümüz Karahöyük Dağı ve çevresinde 2016-2018 yılları arasında ekibimiz tarafından bir yüzey araştırması çalışması gerçekleştirilmiştir $^{6}$ (Fig. 2). Bölgede geçmiş yıllarda gerçekleştirilen yüzey araştırması çalışmalarına ek bilimsel katkılar yapılabileceği düşüncesiyle başlanılan çalışmalarda yeni höyük ve yamaç yerleşimleri saptanmıştır. Araştırmalar sonucunda Karahöyük Dağı'nın çevresinde dokuz tane höyük ve yamaç yerleşimi tespit edilmiştir (Fig. 3).

Karahöyük Dağı ve çevresinde iskanların Geç Neolitik Çağ’dan itibaren başladığı bilinmektedir. Söz konusu alanda dağın yakın çevresinde yer alan Akhisar Höyük ${ }^{7}$, Moralılar

\footnotetext{
${ }^{1}$ David H. French, "Prehistoric Sites in Northwest Anatolia II. The Balikesir and Akhisar/Manisa Areas", Anatolian Studies 19, 1969, s. 47, 49-50.

2 Rafet Dinç, "Kulaksızlar Mermer İdol Atölyesi ve Çevre Araştırmaları”, 14. Araştırma Sonuçları Toplantısı 2, Ankara 1997, s. 266-267, Resim 19-21.

${ }^{3}$ Engin Akdeniz, "2007 Yılında Manisa İli ve İlçelerinde Yürütülen Prehistorik-Protohistorik Yüzey Araştırmaları”, 26. Araştırma Sonuçları Toplantısı 2, Ankara 2009, s. 256-257; Engin Akdeniz, "2008 Yılında Manisa İli ve İlçelerinde Yürütülen Prehistorik-Protohistorik Yüzey Araştırmaları”, 27. Araştırma Sonuçları Toplantısı 1, Ankara 2010a, s. 154; Engin Akdeniz, Prehistorik-Protohistorik Çağlarda Manisa ve Çevresi, TÜBİTAK Projesi Sosyal ve Beşeri Bilimler Araştırma Grubu Başkanlığı, Basılmamış 107K030 No.lu Projenin Sonuç Raporu (SOBAG), Aydın 2010b, s. 21-23, Resim 23-28 (Akhisar Höyük), s. 37-41, Resim 52-58 (Dağdeviren Höyügü̈), s. 55-62, Resim 93101 (Moralılar Höyüğü), s. 62-63, Resim 102-103 (Örentepe I), s. 63-64, Resim 104-106 (Örentepe II), s. 64-65, Resim 107-109 (Rahmiye II).

${ }^{4}$ Christopher H. Roosevelt, Gyges'ten Büyük İskender'e Lydia Arkeolojisi, Koç Üniversitesi Yayınları, İstanbul 2017, s. 292. C. Roosevelt Lydia Arkeolojisi ile ilgili yayınında Karahöyük Dağının güney eteklerindeki yerleşim ve taş ocaklarına da değinmiştir. Söz konusu yayında Karahöyük Dağı'ndan “Karayunt Dağı” olarak bahsedilmektedir.

${ }^{5}$ Turan Takaoğlu, "Moralı: A Neolithic Mound in Central Western Anatolia", Anadolu'da Doğdu-60. Yaşında Fahri Işık'a Armağan (Ed. Taner Korkut, Havva İşkan, Gün Işın), Ege Yayınları, İstanbul 2004, s. 743-751. T. Takalıoğlu Neolitik Çağ’ın önemli yerleşimlerinden olan Moralılar Höyüğ̈̈nü ayrıntılı olarak incelemiştir.

${ }^{6}$ Aydın Erön-Engin Akdeniz-Murat Çekilmez-Merve S. Çakan, "2016 Yılı Karahöyük Dağı Arkeolojik Yüzey Araştırması Çalışmaları", 35. Araştırma Sonuçları Toplantısı 1, Bursa 2018, s. 147-161; Aydın Erön-Engin Akdeniz-Murat Çekilmez-Merve S. Çakan-Emrah Maden-Sezar Kızıl, "2017 Y1lı Akhisar Karahöyük Dağı Yüzey Araştırması Çalışmaları”, 36. Araştırma Sonuçları Toplantısı 1, Çanakkale 2019, s. 237-248.

${ }^{7}$ Akdeniz, agb, s. 22; Engin Akdeniz, "Neolitik Çağ'da Manisa Yöresi”, OLBA XIX, 2011a, s.10; Engin Akdeniz, Tarih Öncesinden İlk Demir Çă̆ı'na Manisa, Akhisar 2011b, s. 15; Engin Akdeniz, "Manisa Yöresindeki
} 
Höyüğ̈̈ ${ }^{8}$ ve Kocanadas Mevkii'nde yer alan höyükte ${ }^{9}$ Geç Neolitik Çağ’a tarihlendirilen seramik buluntuları tespit edilmiştir. Karahöyük Dağı ve çevresinde yer alan birçok höyük ve yamaç yerleşiminde iskanın Osmanlı Dönemi’ne kadar devam ettiği buluntular 1şı̆̆ında bilinmektedir.

Ekibimiz tarafından gerçekleștirilen yüzey araștırmaları sırasında dağın çevresinde yer alan eskiden "köy" günümüzde ise "mahalle" olarak adlandırılan yerleşimlere de gidilerek incelemelerde bulunulmuştur. Söz konusu çalışma içerisinde Karahöyük Dağı'nın güneyinde yer alan Moralılar ve Rahmiye mahalleleri ile batısında yer alan Kayalığlu Mahallesi'nde yer alan devşirme mimari malzeme kullanımı konusu incelenmiştir.

Mahallelerde devşirme malzeme olarak kullanılmış mimari parçaları tanıtmadan önce eski "köy", yeni "mahalleler" hakkında bilgi vermek yararlı olacaktır. Çalışma kapsamında incelenecek olan mahalleler Akhisar ilçesine bağlıdır. Akhisar, yüzölçümü olarak Manisa ilinin en büyük ilçesi konumundadır ${ }^{10}$. Arkeolojik yüzey araştırması çalışmaları gerçekleştirdiğimiz Karahöyük Dağı, Akhisar ilçe merkezinin $4 \mathrm{~km}$ güneybatısında yer almaktadır. Karahöyük Dağı'nın güneyinde yer alan Moralılar Mahallesi, Akhisar ilçe merkezine $7 \mathrm{~km}$ uzaklıktadır. 2015 yılı nüfus sayımına göre mahallede 161 kişi yaşamaktadır ${ }^{11}$. Karahöyük Dağı'nın yine güneyinde yer alan 82 kișinin yaşadığı Rahmiye Mahallesi ise ilçe merkezinin $13 \mathrm{~km}$ güneybatısında yer almaktadır ${ }^{12}$. Bereketli Akhisar Ovası üzerinde yer alan her iki mahalledeki nüfusun azlığı dikkat çekicidir. Tarıma elverişli toprakların olmasına rağmen mahallelerin sürekli göç vermesi incelenmesi gereken bir konudur. Çalışma kapsamında incelenecek olan son yerleşim Kayalıŏlu Mahallesi’dir. Karahöyük Dağı'nın batısında yer alan yerleşim Akhisar ilçe merkezine 7 km uzaklıktadır.

\section{Moralılar Mahallesi}

Karahöyük Dağı'nın güneyinde yer alan Moralılar Mahallesi, 2016 yılı yüzey araştırması çalışmaları sırasında incelenmiştir ${ }^{13}$. Moralılar Mahallesi'nde gerçekleştirilen çalışmalarda 21 adet mimari parça tespit edilmiştir. Mimari parçaların önemli bir bölümü mermer ve travertenden yapılmıştır (Fig. 4). Devşirme malzeme olarak kullanılan eserlerin büyük çoğunluğu mahallenin merkezi olarak adlandırabileceğimiz meydan ve caminin bulunduğu alanda karşımıza çıkmaktadır. Caminin kuzeyinde mimari parçalar kullanılarak bir çeşme yapıldığ 1 tespit edilmiştir (Fig. 5). Mermer bir sütun parçasının içi oyularak su borusu geçirilmiştir. Çeşme teknesi olarak dasit bir blok kullanılmıştır. Dasit bloğun her iki yanında yer alan traverten sütun parçaları çeşme teknesini sabitlemek için kullanılmıştır. Mahalle meydanının köşelerine de genellikle sütun gövdesi parçaları yerleştirilmiştir.

Prehistorik-Protohistorik Buluntu Merkezlerinin Dönemsel ve Coğrafi Dağılımları”, Akdeniz Sanat Dergisi, Cilt 3, Say1 6, 2013b, s. 8.

${ }^{8}$ French, agm, s. 50; Dinç, agm, s. 266-267; Takaoğlu, agm, s. 743-751; Clemens Lichter, "Western Anatolia in the Late Neolithic and Early Chalcolithic: the actual state of research", Byzas 2 (Ed. C. Lichter), 2005, s. 61-63,66; Akdeniz, agm, s. 256; Akdeniz, agb, s. 56-61; Akdeniz, agm, s. 11, Fig. 5; Akdeniz, age, s. 20; Akdeniz, agm, s. 8, Foto. 27; Erön-Akdeniz-Cekilmez-Çakan, agm, s. 151-152, Resim 6-7.

${ }^{9}$ Karahöyük Dağı'nın güneybatısında yer alan Kocanadas Mevkii’nde 2017 yılında ekibimiz tarafından bir höyük keşfedilmiştir (Erön-Akdeniz-Çekilmez-Çakan-Maden-Kızıl, agm, s. 241-242, Resim 10-12). 2018 yılı araştırmaları sırasında yerleşimde Geç Neolitik-Erken Kalkolitik Çağ'a tarihlendirilen seramik parçaları tespit edilmiştir.

10 Zeki Koday-Ferdi Akbaş-Günay Kaya, “Akhisar Büyükşehir İlçesinin İdari Coğrafya Analizi”, Atatürk Üniversitesi Sosyal Bilimler Enstitüsü Dergisi 21(2), 2017, s. 444.

11 agm, s. 449, Tablo 2.

12 agm

${ }^{13}$ Erön-Akdeniz-Çekilmez-Çakan, agm, s. 152, Resim 8.

\section{History Studies}


Evlerin girişlerinin yanında da devşirme malzeme olarak kullanılmış mimari parçalara rastlanmıştır. Girişlerin hemen yanında devşirme malzemelerin kullanılmış olması oldukça ilginçtir. Mahalle halkıyla yapılan görüşmeler sonucunda söz konusu parçaların görsellikten ziyade işlevsel olması için evlerin girişlerine konulduğu anlaşılmıştır. Mahallede araç kullanımının yaygınlaşmasından önce ulaşım ve taşıma işlerinde binek hayvanlarının kullanıldığını ifade etmişlerdir. Mimari parçaları da binek hayvanlarının üzerine binip inmek için kullandıklarını söylemişlerdir.

Moralılar Mahallesi'nde incelenen eserlerin önemli bir bölümünü sütun gövdesi (Fig. 6) ve mimari blok parçaları oluşturmaktadır. Söz konusu parçaların yanı sıra birer adet sütun başlığı ve sütun kaidesinin devşirme malzeme olarak kullanıldığ 1 tespit edilmiştir (Fig. 7). Sütun gövdesi parçalarının önemli bir bölümünün yekpare bloklardan kesilerek kullanıldığ anlaşılmaktadır. Tambur şeklinde düzenlenmiş bir sütun gövdesi parçası tespit edilememiştir. Parçaların önemli bir bölümü işçilik olarak çok kaliteli değildir. Mahalle sakinleri ile yapılan görüşmelerde söz konusu parçaların önemli bir bölümünün Moralılar yakınlarındaki tarlalardan getirildiği bilgisine ulaşılmıştır.

Moralılar Mahallesi'nde bulunan sütun başlı̆̆ 1 ve sütun kaidesi örnekleri işçilik olarak diğer parçalardan ayrılmaktadır. Bir evin giriş kapısı yanında yer alan Dor sütun başlığ parçası mermerden yapılmıştır (Fig. 8). Mahallede tespit edilen diğer mimari parçalara kıyasla işçiliği çok daha iyidir. Eserin abakus bölümü kırıktır. Ekhinus bölümü dışbükey kavisli bir yapıdadır. Z. Gider Büyüközer söz konusu profile sahip ekhinus örneklerinin Hellenistik Dönem'de başladığını belirtmektedir. Fakat Hellenistik Dönem'e tarihlendirilen örnek sayısı oldukça azdır. Dışbükey kavisli ekhinus örneklerinin genelde Roma Dönemi'ne tarihlendirildiğini ifade etmiştir $^{14}$. Ekhinus bölümünün altında basamak biçimli annuletler ve iç bükey profilli bir bant bulunmaktadır. Annuletlerin işçiliği MÖ 29-28 yılları arasına tarihlendirilen Aphrodisias Tiyatrosu proskenionu ${ }^{15}$ ve Augustus Dönemi'ne tarihlendirilen Stratonikeia Tiyatrosu scaenae frons ${ }^{16}$ örneklerine benzemektedir. Başlığın sütun gövdesi ile birleştiği yerde karşımıza çıkan yarım daire biçimli bezemeler Pergamon ${ }^{17}$ ve Kadyanda ${ }^{18}$ örneklerini hatırlatmaktadır. Gider Büyüközer söz konusu bezemeye sahip eserlerin Augustus-Tiberius Dönemi arasına tarihlenebileceğini belirtmiştir ${ }^{19}$. Moralılar Mahallesi buluntusu Dor sütun başlığı benzer örnekler yardımıyla Augustus Dönemi'ne tarihlenebilir.

Yine bir evin giriş kapısı yanında bulunan Attik-Ion tipi sütun kaidesi parçası da oldukça önemlidir ${ }^{20}$ (Fig. 9). Mermerden yapılmış eser büyük oranda sağlamdır. Plinthos bölümü en çok tahrip edilen bölüm olarak karşımıza çıkmaktadır. Alt torus profili üzerinde herhangi bir bezemeye yer verilmemiştir. Trokhilos bölümü de yine bezemesizdir. Eserin üst torus profilinin sütun tamburu ile bir yapıldığı anlaşılmaktadır. Vitruvius, Ion düzenli yapıların sütun oranları ile ilgili bilgi verdiği bölüm içerisinde Attik-Ion tipi kaidelere de değinmiştir ${ }^{21}$. Anadolu'da Attik-Ion tipi sütun kaidelerinin Hellenistik Dönem'den itibaren kullanılmaya başlandıkları

14 Zeliha Gider Büyüközer, Karia Bölgesi Dor Mimarisi, (Selçuk Üniversitesi, Sosyal Bilimler Enstitüsü, Yayınlanmamış Doktora Tezi), Konya 2013, s. 65-66.

15 Frank Rumscheid, Untersuchungen zur Kleinasiatischen Bauornamentik des Hellenismus, Beiträge zur Erschließung hellenistischer und kaiserzeitlicher Skulptur und Architektur 14, Mainz 1994, s. 9, Tafel 10.4 (17.1-2).

${ }^{16}$ Gider Büyüközer, agm, s. 731-732, Figür 428-429.

${ }^{17}$ Rumscheid, age, Tafel 141.2 (288).

18 age, Tafel 52.11 (76).

19 Gider Büyüközer, agm, s. 105.

${ }^{20}$ Eserin korunan yükssekliği $23 \mathrm{~cm}$ dir. Alt torus bölümü 79,5 cm çapındadır. Üst torus bölümünün $61,6 \mathrm{~cm}$ çapında bir alana oturacağ

${ }^{21}$ Vitruvius, Mimarlık Üzerine, (De Architectura), (Çev. Çiğdem Dürüşken), Alfa Yayıncılık, İstanbul 2017, III, 5, 2. 
bilinmektedir ${ }^{22}$. Roma İmparatorluk Dönemi içerisinde ise kullanımları bir hayli artmıştır. Anadolu'da Roma İmparatorluk Dönemi'ne tarihlendirilen birçok yapıda Attik-Ion tipi sütun kaidesi kullanılmıştır ${ }^{23}$. Kaidelerin tarihlendirilmesinde genellikle üzerindeki bezemelerden yararlanılmaktadır. Bezemesiz sütun kaidelerinin profilleri genelde benzer olduğu için tarihlendirmek oldukça sıkıntılıdır. Moralılar Mahallesi buluntusu eser, işçilik olarak Roma İmparatorluk Dönemi örneklerini hatırlatmaktadır.

\section{Rahmiye Mahallesi}

Rahmiye Mahallesi de Karahöyük Dağı'nın güneyinde yer almaktadır. Moralılar Mahallesi'nin kuş uçuşu 4500 m batısında yer alan küçük yerleşim 2016 yılı yüzey araştırması çalışmaları sırasında incelenmiştir ${ }^{24}$. Rahmiye Mahallesi sınırları içerisinde 30 adet devşirme malzeme olarak kullanılan mimari yapı parçası tespit edilmiştir. Mimari parçaların önemli bir bölümü mermer ve dasitten yapılmıştır (Fig. 10). Yapılan incelemeler sonucunda 13 tanesinin profilli veya düz mimari blok niteliğinde parça olduğu tespit edilmiştir. Devşirme malzeme olarak kullanılan parçaların yine önemli bir bölümünü sütun gövdesi parçaları oluşturmaktadır (Fig. 11).

Moralılar Mahallesi'nde olduğu gibi mimari parçaların bir bölümü yerleşimin meydanına yakın bir alanda karşımıza çıkmaktadır. Mahalle meydanında yapılan çevre düzenlemeleri sırasında sütun gövdesi parçalarının bir düzen dahilinde alana yerleştirildiği anlaşılmaktadır (Fig. 12). Söz konusu parçaların üzeri ne yazık ki kireç ile boyanmıştır. Büyük oranda terk edilmiş mahallede yaptığımız incelemeler sırasında çoğunluğu evlerin giriş kapıları önünde olmak üzere devşirme malzeme olarak kullanılmış mimari yapı parçaları tespit edilmiştir.

Rahmiye Mahallesi’nde yapılan incelemeler sırasında bulunan parçaların önemli bir bölümü kaliteli eserler değildir. Alanda incelenmeye değer nitelikte iki adet mimari parça saptanmıştır. Söz konusu eserlerden ilki bir Dor sütun başlığı parçasıdır (Fig. 13). Dasit malzemeden yapılmış olan eserin korunan yüksekliği $23 \mathrm{~cm}$ dir. Dasit, bölge için yerel bir malzemedir. İşlemesi çok kolay değildir. Söz konusu nedenle bölgede bulunan dasit malzemeler daha çok yapıların temellerinde kullanılmıştır. Dasitin sütun başlığı olarak kullanılması bölgede çok karşılaştı̆̆ımız bir durum değildir. Arkeolojide yerel taş cinslerinin yapılarda kullanımı karşımıza çıkan bir durumdur. Tarihlendirilmeleri de oldukça risklidir. Erken dönem kullanımı olabileceği gibi geç yani Bizans Dönemi olabilme durumu da vardır. Yerel malzemenin erken dönem kullanımına örnek olarak Alinda ve Alabanda örneklerini verebiliriz. Karia Bölgesi'nin önemli yerleşimleri arasında yer alan Alinda ve Alabanda'da yerel bir taş cinsi olan gnays kullanılarak yapılar inşa edildiği bilinmektedir. Hatta Alinda Agorası ${ }^{25}$ ve Alabanda Tiyatrosu'nda ${ }^{26}$ bulunan Dor stili başlıklar gnaystan yapılmıştır.

Attik-Ion tipi sütun kaidesi incelenebilinecek nitelikte bir diğer eserdir (Fig. 14). Mermerden yapılmış olan eser büyük oranda sağlam olarak bulunmuştur. $21 \mathrm{~cm}$ yüksekliğinde

\footnotetext{
${ }^{22}$ Lucy Shoe Meritt, "The Geographical Distribution of Greek and Roman Ionic Bases”, Hesperia 38.2, 1969, s. 191; A. Oğuz Alp, "Hellenistik-Roma Dönemi Anadolu Mimarlığında Bezemeli Kaideler”, Anadolu/Anatolia 34, 2008, s. 30.

${ }^{23}$ Shoe Meritt, agm, s. 196, dipnot 40.

${ }^{24}$ Erön-Akdeniz-Çekilmez-Çakan, agm, s. 153, Resim 12.

${ }^{25}$ Seyhan Doruk, "Antik Alinda Kentindeki Pazar Yapısı”, Belleten Cilt LI, Say1 201, 1987, s. 1117-1137. S. Doruk Alinda Agorasını plan ve işçilik özelliklerini dikkate alarak MÖ 2. yüzyılın başlarına tarihlemiştir.

26 S. Ateşlier, Alabanda Tiyatrosu'nda devşirme malzeme olarak kullanılan Dor sütun başlıklarının Zeus Khrysaoreus Tapınağı'ndan getirildiğini tespit etmiştir. Zeus Khrysaoreus Tapınağı'nın MÖ 4. yüzyıla tarihlendirilmesi gerektiğini ifade etmiştir. Tapınak hakkında bilgi ve tarihlendirme için bkz; Suat Ateşlier, "On the Excavations of the Zeus Temple of Alabanda", Anatolia Antiqua XXII, 2014, s. 247-254; Suat Ateşlier-Sedat Akkurnaz, “2011-2012 Yılı Alabanda Kazıları”, 35. Kazı Sonuçları Toplantısı 3, Muğla 2014, s. 488-489.
}

\section{History Studies}


olan kaidenin plinthosu 49x49 $\mathrm{cm}$ ölçülerindedir. Alt torus profili üzerinde bezeme yoktur. Trokhilos bölümü üzerinde de bezemeye yer verilmemiştir. Eserin üst torus bölümü $38 \mathrm{~cm}$ çap ölçüsüne sahiptir. Eser işçilik olarak Roma İmparatorluk Dönemi örneklerini hatırlatmaktadır.

Rahmiye Mahallesi'nde bulunan parçaların önemli bir bölümü işçilik olarak çok nitelikli eserler değildir. Parçalar genel işçilik ve özelliklerine bakılarak Roma Dönemi'ne tarihlendirile bilinir.

\section{Kayalığlu Mahallesi}

Kayalığlu Mahallesi, Karahöyük Dağı'nın batısında yer almaktadır. Söz konusu alan $2017^{27}$ ve 2018 yılı yüzey araştırması çalışmaları sırasında incelenmiştir. Mahalle sınırları içerisinde toplam 17 mimari parça tespit edilmiştir. Yapılan incelemeler sonucunda eserlerin önemli bir bölümünün sütun gövdesi parçası olduğu tespit edilmiştir (Fig. 15). Söz konusu mimari parçaların büyük çoğunluğu mermerden yapılmıştır (Fig. 16).

Kayalığlu Mahallesi içerisinde tespit edilen parçaların yine önemli bir bölümü konut girişleri yanında karşımıza çıkmaktadır (Fig. 17). Bezemeli bir parça ne yazık ki bulunamamıştır. 2018 yılı çalışmaları sırasında bulunan bir parçanın üzerindeki silme profillerinden yola çıkarak üç fascialı bir architrave olabileceği düşünülmüştür. Fakat parça tahrip olduğu için net bir şey söylemek oldukça zordur. Ayrıca yine 2018 yılı araştırmaları sırasında bir konutun sokak kapısının yanında bir Dor sütun başlığı parçası bulunmuştur (Fig. 18). Üzeri kireç ile boyanmış olan eserin çapı $44,5 \mathrm{~cm}$ dir. Başlıkta silme profilinin izi görülmektedir. Eser oldukça tahrip olmuş durumdadır. Her iki eserin de dönemini tespit etmek oldukça zordur. Ama genel özellikleri itibariyle Roma Dönemi örneklerini hatırlatmaktadırlar. Kayalıŏlu Mahallesi'nde bulunan parçaların tamamına bakıldığında mimari eserler genel olarak Roma ve Geç Antik Çağ özellikleri göstermektedir.

\section{Sonuç}

Karahöyük Dağı ve çevresinde 2016-2018 yılları arasında gerçekleştirdiğimiz yüzey araştırması çalışmaları sırasında çok sayıda mimari yapı parçası tespit edilmiştir. Söz konusu mimari parçaların önemli bir bölümü dağın güney ve batısında yer alan mahalleler içerisinde bulunmuştur (Fig. 19). Moralılar, Rahmiye ve Kayalıoğlu mahallelerinde bulunan eserlerin büyük çoğunluğunu sütun gövdesi ve profilsiz mimari yapı parçaları oluşturmaktadır (Fig. 20). Araştırma sahası içerisinde yer alan mahallelerin tamamında Dor sütun başlı̆̆ parçaları tespit edilmiştir. Bu durum oldukça ilginçtir. Bölgede çoğunlukla Ion düzeninin tercih edildiği bilinmektedir. Mahallelerde yapılan incelemeler sonucunda en çok mermer ve dasit malzemeden yapılmış mimari parçaların devşirme malzeme olarak kullanıldığı anlaşılmıştır (Fig. 21). Mimari parçaların önemli bir bölümünü tarihlendirmek oldukça zordur. Devşirme malzeme olarak kullanılan eserlerin büyük çoğunluğu Roma Dönemi örneklerini hatırlatmaktadır.

Karahöyük Dăğ'nın güneyinde yer alan Moralılar ve Rahmiye mahallelerinde bulunan mimari yapı parçalarının neredeyse tamamının devşirme malzeme olarak kullanıldığ 1 tespit edilmiştir. Parçaların önemli bir bölümü mahalle meydanlarında ve evlerin giriş kapıları yanında yer almaktadır. Dağın batısında yer alan Kayalıoğlu Mahallesi'nde de benzer bir kullanım söz konusudur. Çalışma sırasında tespit edilen mimari eserlerin çok önemli bir bölümünü bezemesiz parçalar oluşturmaktadır. Özellikle Kayalığlu Mahallesi'nde bezemeli eser sayıs1 yok denecek kadar azdır.

\footnotetext{
${ }^{27}$ Erön-Akdeniz-Çekilmez-Çakan-Maden-Kızıl, agm, s. 242, Resim 13.
}

\section{History Studies}


Söz konusu mahallelerde saptanılan mimari yapı parçalarının önemli bir bölümünün yakınlarında yer alan höyük yerleşimlerinden getirilmiş olma ihtimalleri oldukça yüksektir. Moralılar Mahallesi'nin yakınlarında Moralılar ve Örentepe höyükleri, Rahmiye Mahallesi'nin yakınlarında ise Rahmiye II ve Kocanadas Mevkii'nde yer alan höyükler bulunmaktadır. Kayalıoğlu Mahallesi yakınlarında önemli bir höyük yerleşimi tespit edilememiştir.

Oldukça bereketli Akhisar Ovası üzerinde yer alan Moralı, Rahmiye ve Kayalığlu mahalleleri çevresinde tarımsal faaliyetler en önemli geçim kaynağını oluşturmaktadır. Yılda birçok kez verim alınabilinecek nitelikte arazilere sahip olunmasına rağmen mahallelerdeki nüfus günden güne azalmaktadır. Özellikle Rahmiye Mahallesi’nde yaşayan kişi sayısı oldukça azdır. Yöre halkı özellikle genç nüfusun iş bulmak için Akhisar ilçe merkezine taşındığını ifade etmiştir. Kayalıoğlu Mahallesi’nin durumu günümüz Balıkesir-Manisa yolu yanında yer alması nedeniyle Moralılar ve Rahmiye mahallelerine kıyasla biraz daha iyidir.

Karahöyük Dağı ve çevresinin günümüzdeki iskan anlayışı erken dönem yerleşimlerini de anlamamıza olanak sağlamaktadır. Bölgedeki yerleşimlerin karakteri incelendiğinde erken dönem iskanlarının (Geç Neolitik, Kalkolitik, Tunç çağları) ardından Demir Çağı ile birlikte Akhisar ilçe merkezi sınırları içerisinde yer alan yerleşimin ön plana çıtı̆̆ 1 anlaşılmaktadır. Hellenistik Dönem sonrasında Thyateira antik kentinin önemli bir yerleşim yeri niteliği kazandığı çok daha kesindir ${ }^{28}$. Karahöyük Dağı ve çevresinde yer alan höyük ve yamaç yerleşimleri bu tarihlerden sonra da iskan görmeye devam etmiştir. Fakat daha yerel yerleşimlere dönüştükleri buluntulardan anlaşılmaktadır. Bu durum çalışma kapsamında incelenen mimari yapı parçalarından da anlaşılmaktadır.

\section{Kaynakça}

\section{Antik Kaynaklar}

VITRUVIUS, Vitruvius, Mimarlık Üzerine, (De Architectura), (Çev. Çiğdem Dürüşken), Alfa Yayınc1lı, İstanbul 2017.

\section{Modern Kaynaklar}

AKDENIZ, Engin, “2007 Yılında Manisa İli ve İlçelerinde Yürütülen Prehistorik-Protohistorik Yüzey Araştırmaları”, 26. Araştırma Sonuçları Toplantısı 2, Ankara 2009, s. 255-266.

,"2008 Yılında Manisa İli ve İlçelerinde Yürütülen Prehistorik-Protohistorik

Yüzey Araştırmaları”, 27. Araştırma Sonuçları Toplantısı 1, Ankara 2010a, s. 153-174.

\footnotetext{
${ }^{28}$ Bölge coğrafyasının önemli yerleşimleri arasında sayabileceğimiz Thyateira antik kenti ve erken dönem iskanı olan Hastane Höyük alanındaki sistemli kazı çalışmaları 2011 yılından itibaren E. Akdeniz başkanlığındaki bir ekip tarafından gerçekleştirilmektedir. Söz konusu çalışmalar için bkz; Engin Akdeniz, "2011 Y1lı Akhisar-Thyateira Kazıları", 34. Kazı Sonuçları Toplantısı 2, Ankara 2013a, s. 429-444; Engin Akdeniz, "2012 Yılında Thyateira Antik Kenti ve Hastane Höyüğünde Gerçekleștirilen Arkeolojik Çalışmalar”, 35. Kazı Sonuçları Toplantısı 2, Muğla 2014, s. 124-139; Engin Akdeniz-Mustafa Kemal Şahin-Aydın Erön, "2013 Y1lı Akhisar-Thyateira Antik Kenti ve Hastane Höyüğü Kazısı", 36. Kazı Sonuçları Toplantısı 2, Ankara 2015, s. 121-138; Engin Akdeniz-Aydın Erön, "2014 Yı1ı Akhisar-Thyateira Antik Kenti ve Hastane Höyüğü Kazısı”, 37. Kazı Sonuçları Toplantısı 2, Ankara 2016, s. 81-94; Engin Akdeniz-Aydın Erön, "2015 Yılı Akhisar-Thyateira Antik Kenti ve Hastane Höyügü Kazısı", 38 . Kazı Sonuçları Toplantısı 2, Ankara 2017, s. 403-416; Engin Akdeniz-Aydın Erön-Yavuz Selim Kaya, "2016 Yı11 Akhisar-Thyateira Antik Kenti ve Hastane Höyüğü Kazısı", 39. Kazı Sonuçları Toplantısı 2, Bursa 2018, s. 1-14; Engin Akdeniz-Aydın Erön-Nihal Akıllı, "2017 Yılı Thyateira ve Hastane Höyüğü Kazıları", 40. Kazı Sonuçları Toplantısı 1, Ankara 2019, s. 671-682.
} 
, Prehistorik-Protohistorik Çağlarda Manisa ve Çevresi, TÜBİTAK Projesi Sosyal ve Beşeri Bilimler Araştırma Grubu Başkanlığı, Basılmamış 107K030 No.lu Projenin Sonuç Raporu (SOBAG), Aydın 2010b.

, "Neolitik Çă̆' da Manisa Yöresi”, OLBA XIX, 2011a, s. 1-46.

, Tarih Öncesinden İlk Demir Çă̆ı'na Manisa, Akhisar 2011b.

, “2011 Yılı Akhisar-Thyateira Kazıları”, 34. Kazı Sonuçları Toplantısı 2, Ankara 2013a, s. 429-444.

, "Manisa Yöresindeki Prehistorik-Protohistorik Buluntu Merkezlerinin Dönemsel ve Coğrafi Dağılımları", Akdeniz Sanat Dergisi, Cilt 3, Sayı 6, 2013b, s. 126.

, "2012 Yllında Thyateira Antik Kenti ve Hastane Höyüğünde Gerçekleştirilen Arkeolojik Çalışmalar”, 35. Kazı Sonuçları Toplantısı 2, Muğla 2014, s. 124-139.

AKDENIZ, Engin-Mustafa Kemal Şahin-Aydın Erön, "2013 Yılı Akhisar-Thyateira Antik Kenti ve Hastane Höyüğü Kazısı”, 36. Kazı Sonuçları Toplantısı 2, Ankara 2015, s. 121-138.

AKDENIZ, Engin-Aydın Erön, "2014 Yılı Akhisar-Thyateira Antik Kenti ve Hastane Höyüğü Kazısı", 37. Kazı Sonuçları Toplantısı 2, Ankara 2016, s. 81-94.

, "2015 Y11 Akhisar-Thyateira Antik Kenti ve Hastane Höyüğü Kazısı”, 38. Kazı Sonuçları Toplantısı 2, Ankara 2017, s. 403-416.

AKDENIZ, Engin-Aydın Erön-Yavuz Selim Kaya, "2016 Yılı Akhisar-Thyateira Antik Kenti ve Hastane Höyüğü Kazısı”, 39. Kazı Sonuçları Toplantısı 2, Bursa 2018, s. 1-14.

AKDENIZ, Engin-Aydın Erön-Nihal Akı1lı, "2017 Y11ı Thyateira ve Hastane Höyüğü Kazıları”, 40. Kazı Sonuçları Toplantısı 1, Ankara 2019, s. 671-682.

ALP, A. Oğuz, "Hellenistik-Roma Dönemi Anadolu Mimarlığında Bezemeli Kaideler", Anadolu/Anatolia 34, 2008, s. 27-46.

ATEŞLİER, Suat, "On the Excavations of the Zeus Temple of Alabanda", Anatolia Antiqua XXII, 2014, s. 247-254.

ATEŞLİER, Suat-Sedat Akkurnaz, "2011-2012 Yılı Alabanda Kazıları", 35. Kazı Sonuçları Toplantısı 3, Muğla 2014, s. 482-498.

DİNÇ, Rafet, "Kulaksızlar Mermer İdol Atölyesi ve Çevre Araştırmaları", 14. Araştırma Sonuçları Toplantısı 2, Ankara 1997, s. 255-282.

DORUK, Seyhan, “Antik Alinda Kentindeki Pazar Yapısı”, Belleten Cilt LI, Sayı 201, 1987, s. 1117-1137.

ERÖN, Aydın-Engin Akdeniz-Murat Çekilmez-Merve S. Çakan, "2016 Yı1ı Karahöyük Dağı Arkeolojik Yüzey Araştırması Çalışmaları", 35. Araştırma Sonuçları Toplantısı 1, Bursa 2018, s. 147-161.

ERÖN, Aydın-Engin Akdeniz-Murat Çekilmez-Merve S. Çakan-Emrah Maden-Sezar Kızıl, "2017 Yılı Akhisar Karahöyük Dağı Yüzey Araştırması Çalışmaları”, 36. Araştırma Sonuçları Toplantısı 1, Çanakkale 2019, s. 237-248. 
FRENCH, H. David, "Prehistoric Sites in Northwest Anatolia II. The Balikesir and Akhisar/Manisa Areas", Anatolian Studies 19, 1969, s. 41-98.

GİDER BÜYÜKÖZER, Zeliha, Karia Bölgesi Dor Mimarisi, (Selçuk Üniversitesi, Sosyal Bilimler Enstitüsü, Yayınlanmamış Doktora Tezi), Konya 2013.

KODAY, Zeki-Ferdi Akbaş-Günay Kaya, "Akhisar Büyükşehir İlçesinin İdari Coğrafya Analizi”, Atatürk Üniversitesi Sosyal Bilimler Enstitüsü Dergisi 21(2), 2017, s. 443455.

LICHTER, Clemens, "Western Anatolia in the Late Neolithic and Early Chalcolithic: the actual state of research", Byzas 2 (Ed. C. Lichter), 2005, s. 59-74.

ROOSEVELT, H.Christopher, Gyges 'ten Büyük İskender'e Lydia Arkeolojisi, Koç Üniversitesi Yayınları, İstanbul 2017.

RUMSCHEID, Frank, Untersuchungen zur Kleinasiatischen Bauornamentik des Hellenismus, Beiträge zur Erschließung hellenistischer und kaiserzeitlicher Skulptur und Architektur 14, Mainz 1994.

SHOE MERITT, Lucy, "The Geographical Distribution of Greek and Roman Ionic Bases", Hesperia 38.2, 1969, s. 186-204.

TAKAOĞLU, Turan, "Moralı: A Neolithic Mound in Central Western Anatolia", Anadolu'da Doğdu-60. Yaşında Fahri Iş̧ı'a Armağan, Ed. Taner Korkut, Havva İşkan, Gün Işın, Ege Yayınları, İstanbul 2004, s. 743-751. 
Devşirme Mimari Malzeme Kullanımı Üzerine Düşünceler

\section{Figürler Listesi}

Fig. 1-Karahöyük Dağı'nın Yerini Gösteren Harita

Fig. 2-Karahöyük Dağı Haritası

Fig. 3-Karahöyük Dağı ve Çevresinde Tespit Edilen Höyük ve Yamaç Yerleşimleri

Fig. 4-Moralılar Mahallesi’nde Tespit Edilen Mimari Parçaların Malzeme Grafiği

Fig. 5-Moralılar Mahallesi Camisi Girişinde Yer Alan Çeşme

Fig. 6-Moralılar Mahallesi'nde Devşirme Malzeme Olarak Kullanın Sütun Gövdesi Parçaları

Fig. 7-Moralılar Mahallesi’nde Tespit Edilen Mimari Parçaların Grafiği

Fig. 8-Moralılar Mahallesi'nde Tespit Edilen Dor Başlığı

Fig. 9-Moralılar Mahallesi'nde Tespit Edilen Attik-Ion Kaide

Fig. 10-Rahmiye Mahallesi’nde Tespit Edilen Mimari Parçaların Malzeme Grafiği

Fig. 11-Rahmiye Mahallesi'nde Tespit Edilen Mimari Parçaların Grafiği

Fig. 12-Rahmiye Mahallesi'nde Meydanında Devşirme Malzeme Olarak Kullanın Sütun Gövdesi Parçaları

Fig. 13-Rahmiye Mahallesi'nde Tespit Edilen Dor Başlı̆̆1

Fig. 14-Rahmiye Mahallesi'nde Tespit Edilen Attik-Ion Kaide

Fig. 15-Kayalığlu Mahallesi'nde Tespit Edilen Mimari Parçaların Grafiği

Fig. 16-Kayalığlu Mahallesi’nde Tespit Edilen Mimari Parçaların Malzeme Grafiği

Fig. 17-Kayalığlu Mahallesi’nde Tespit Edilen Mimari Parçalardan Görüntüler

Fig. 18-Kayalıŏglu Mahallesi’nde Tespit Edilen Dor Başlı̆̆

Fig. 19-Karahöyük Dağı'nın Çevresindeki Mahallelerde Tespit Edilen Mimari Parça Sayısı

Fig. 20-Karahöyük Dağı'nın Çevresindeki Mahallelerde Tespit Edilen Mimari Parçaların Grafiği

Fig. 21-Karahöyük Dağı'nın Çevresindeki Mahallelerde Tespit Edilen Mimari Parçaların Malzeme 
Aydın Erön

\section{Figürler}

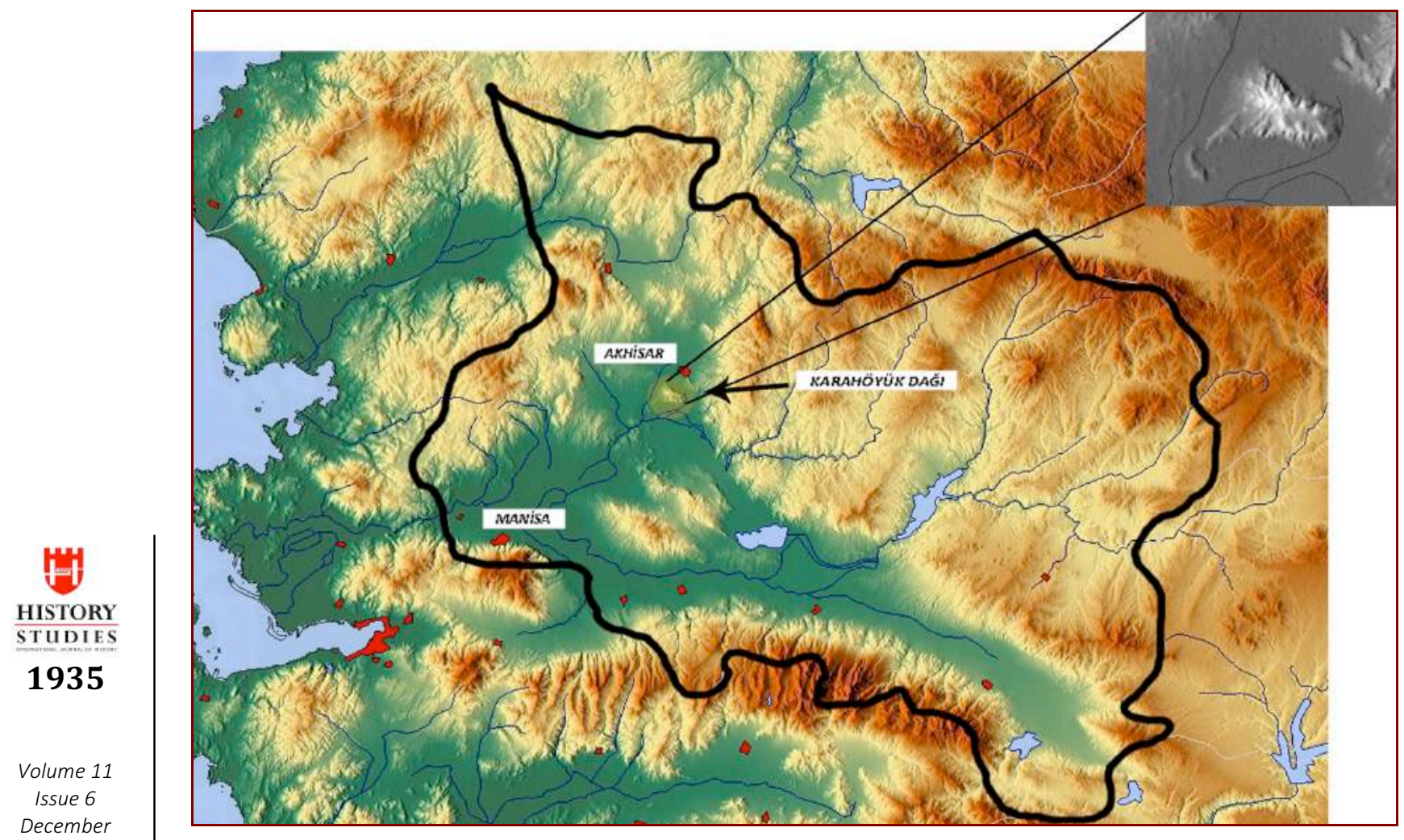

Fig. 1 
Devşirme Mimari Malzeme Kullanımı Üzerine Düşünceler

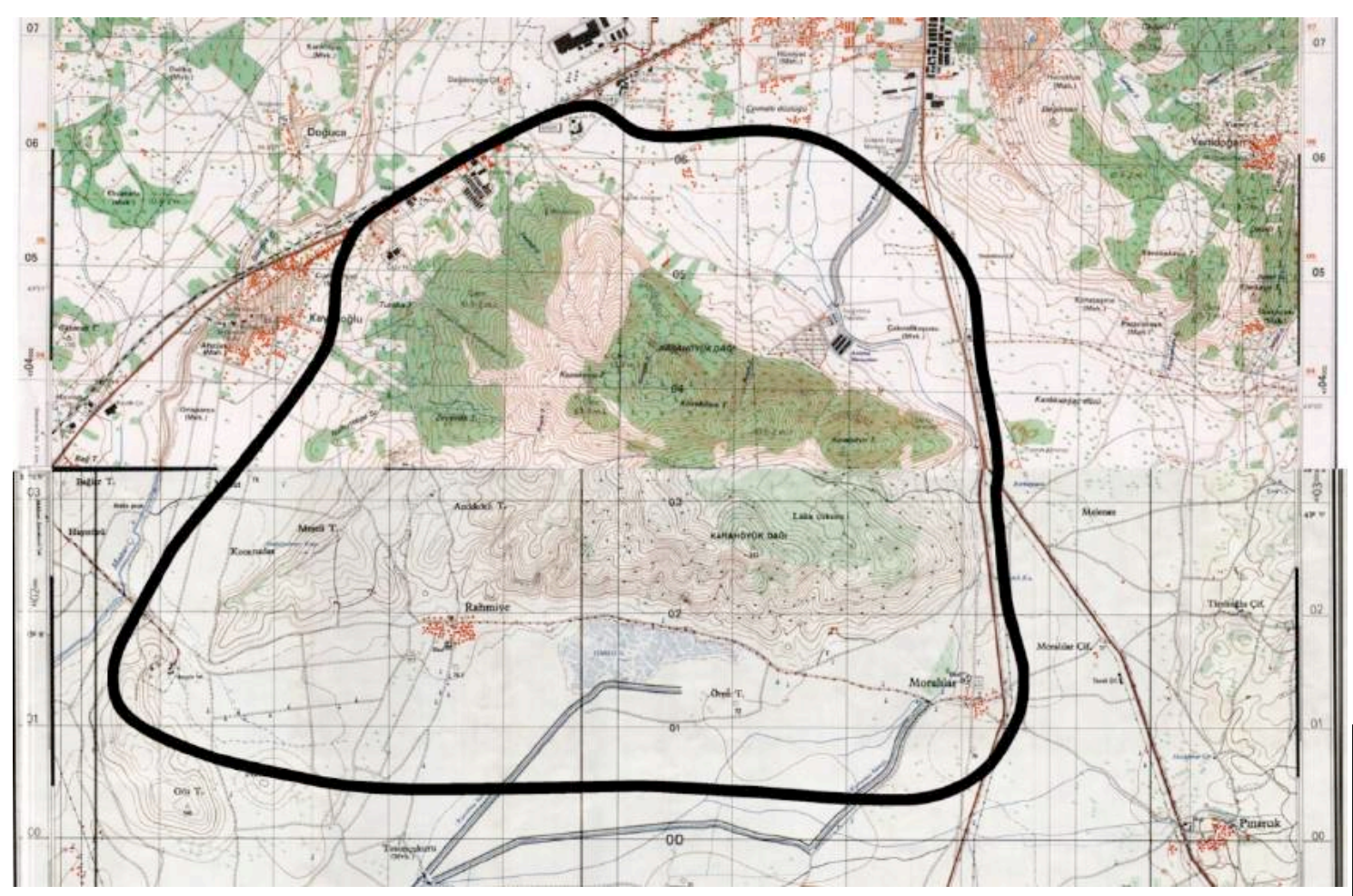

Fig. 2

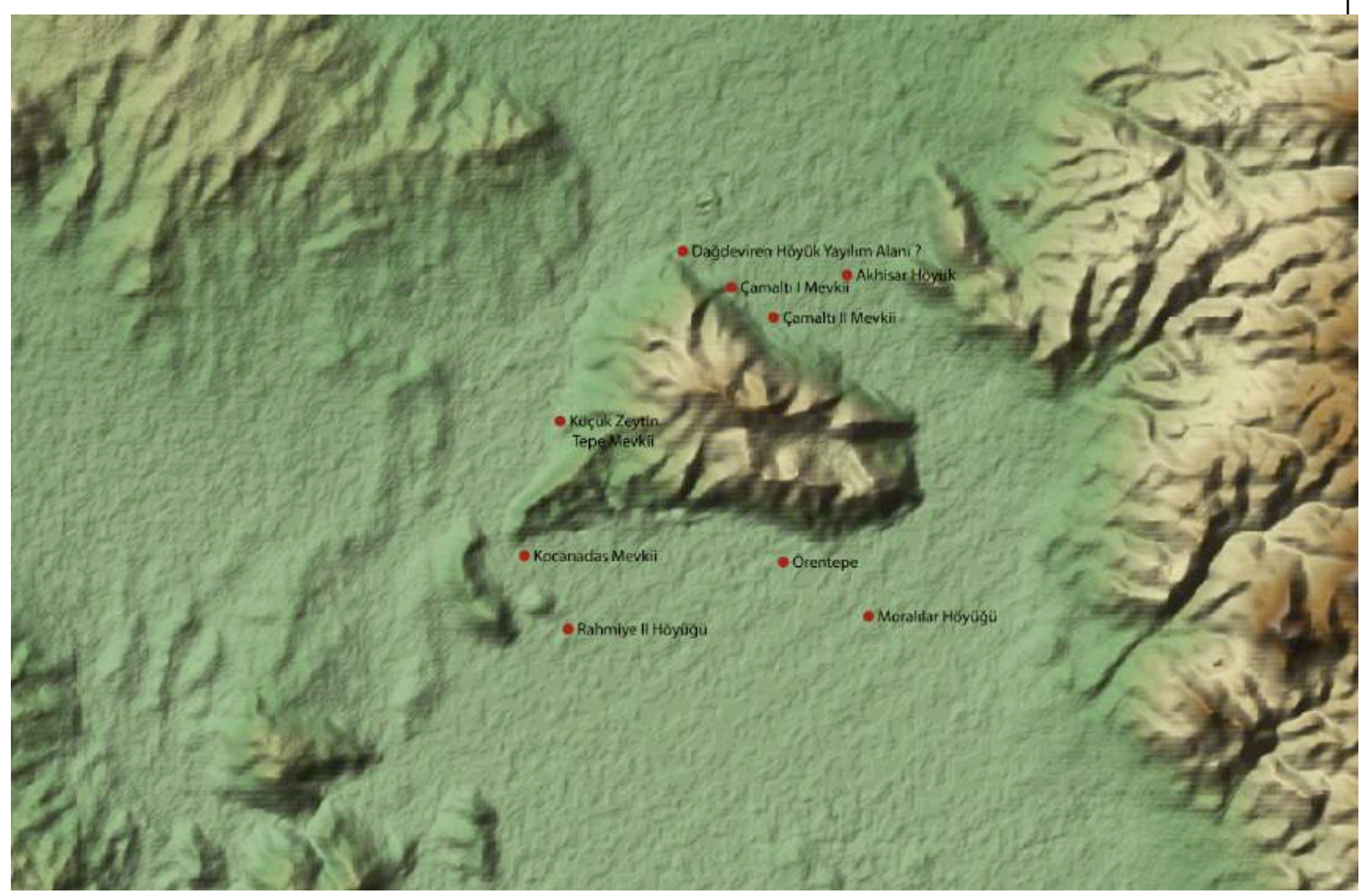

Volume 11

Issue 6 December

Fig. 3 

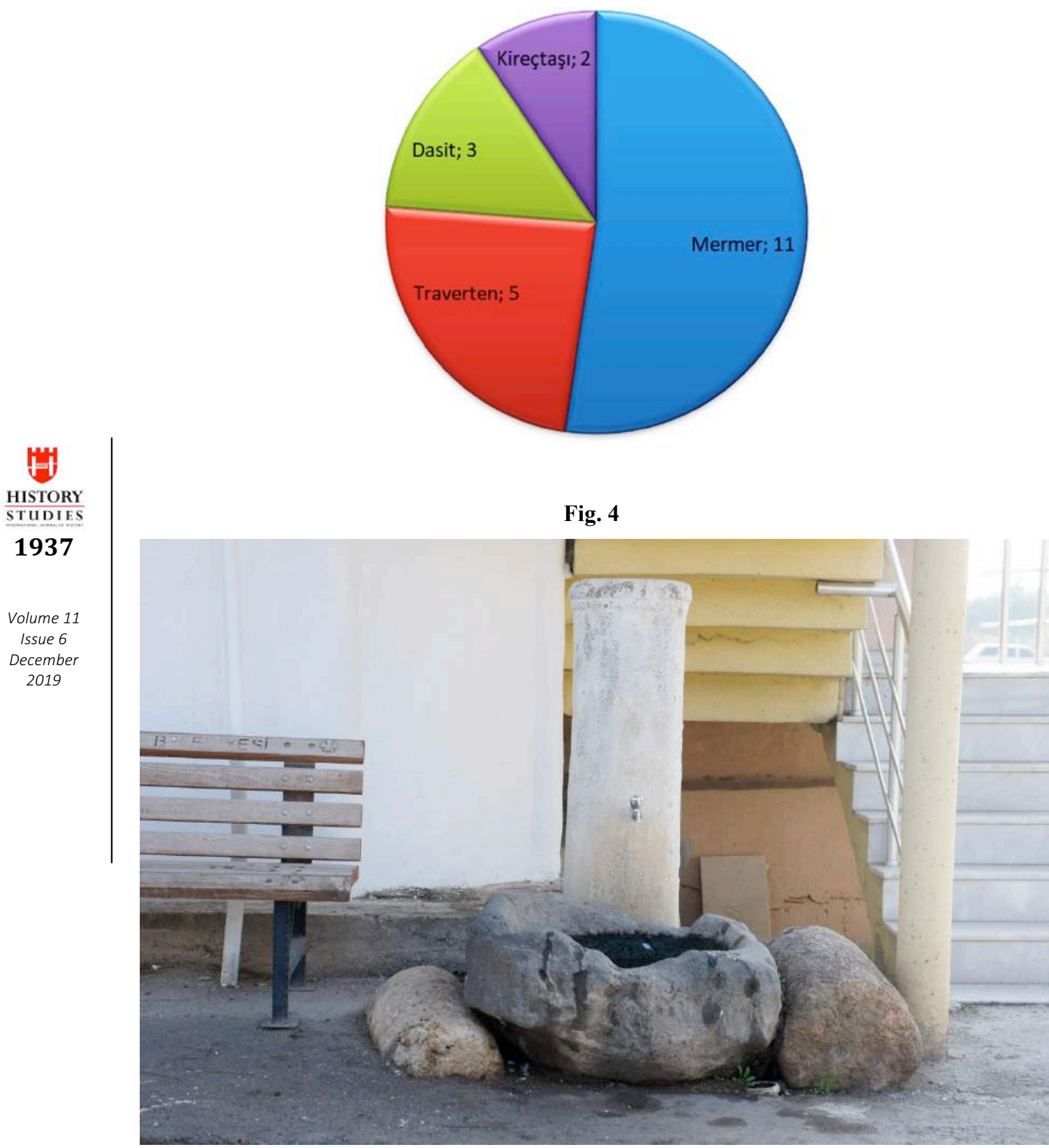

Fig. 5 
Devşirme Mimari Malzeme Kullanımı Üzerine Düşünceler
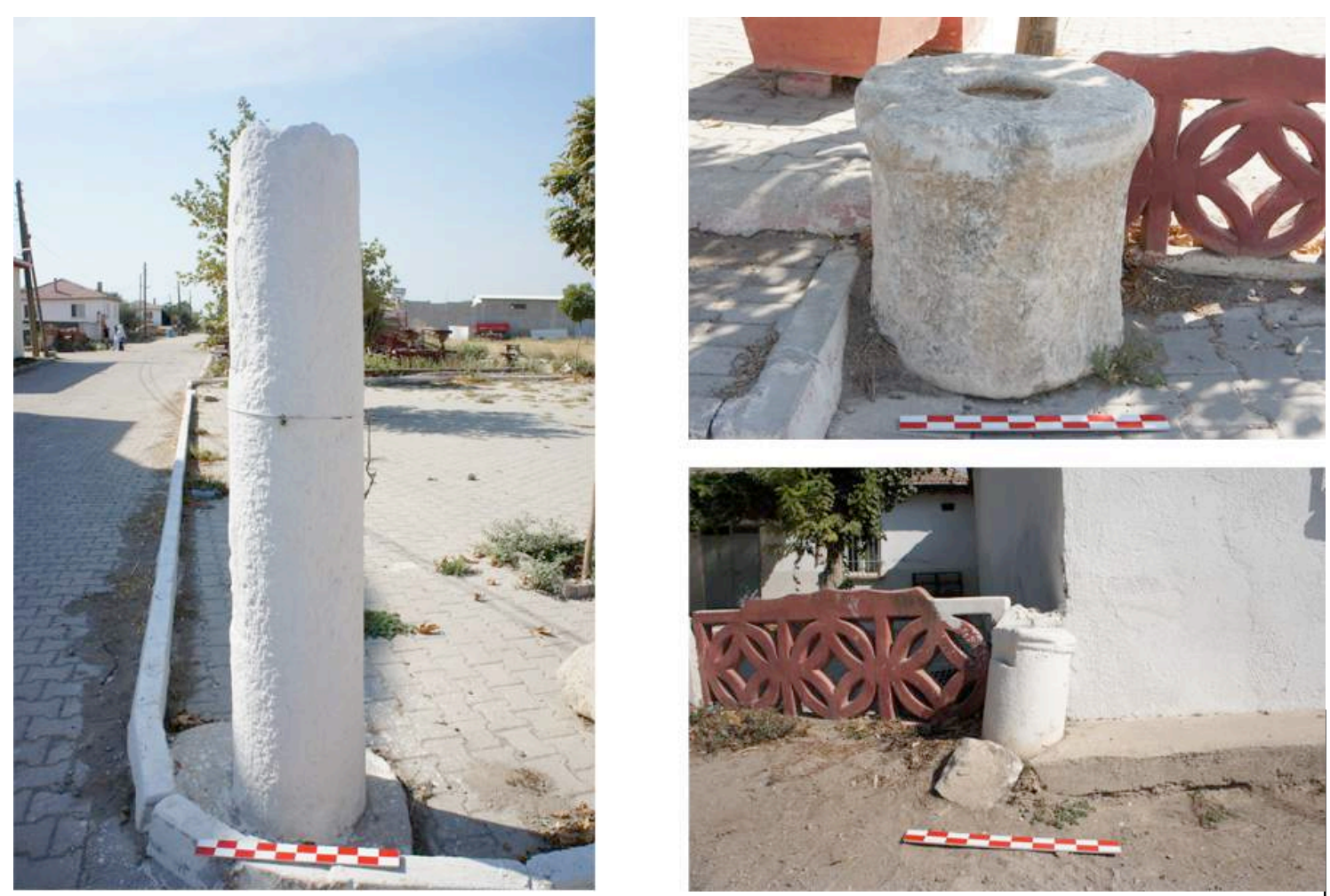

Fig. 6

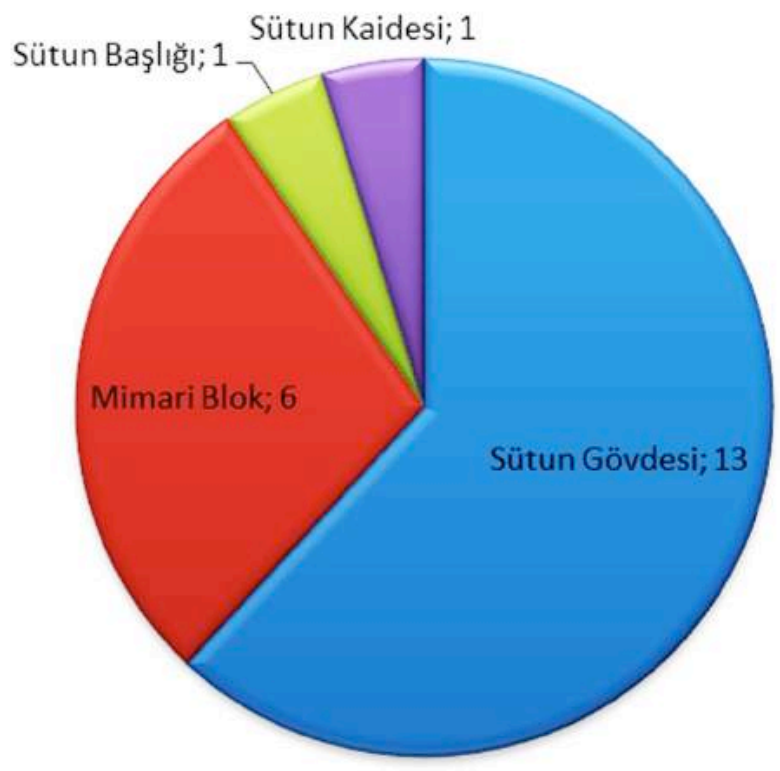

Volume 11

Issue 6

December 2019

Fig. 7 
Aydın Erön

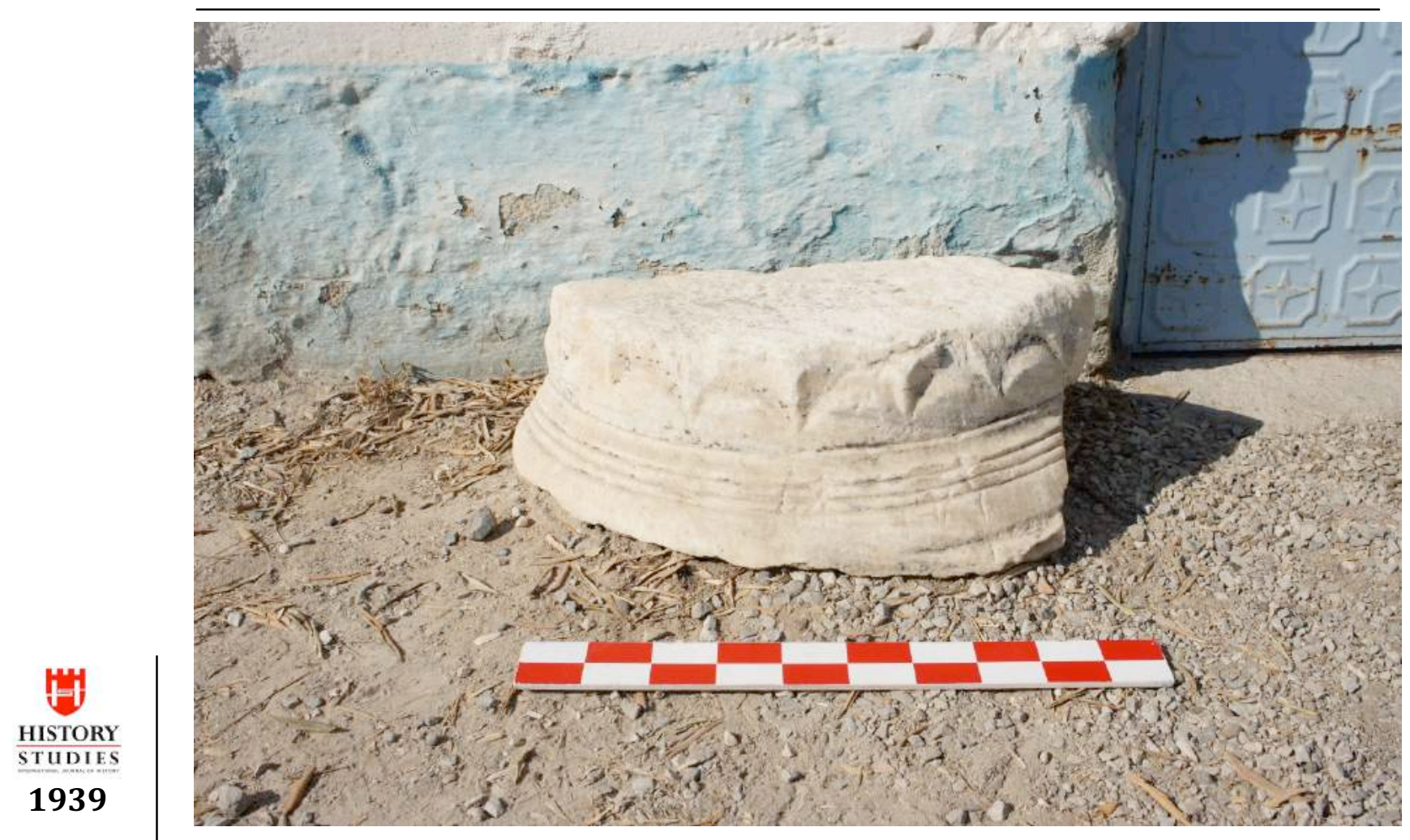

Fig. 8

Volume 11

Issue 6

December

2019

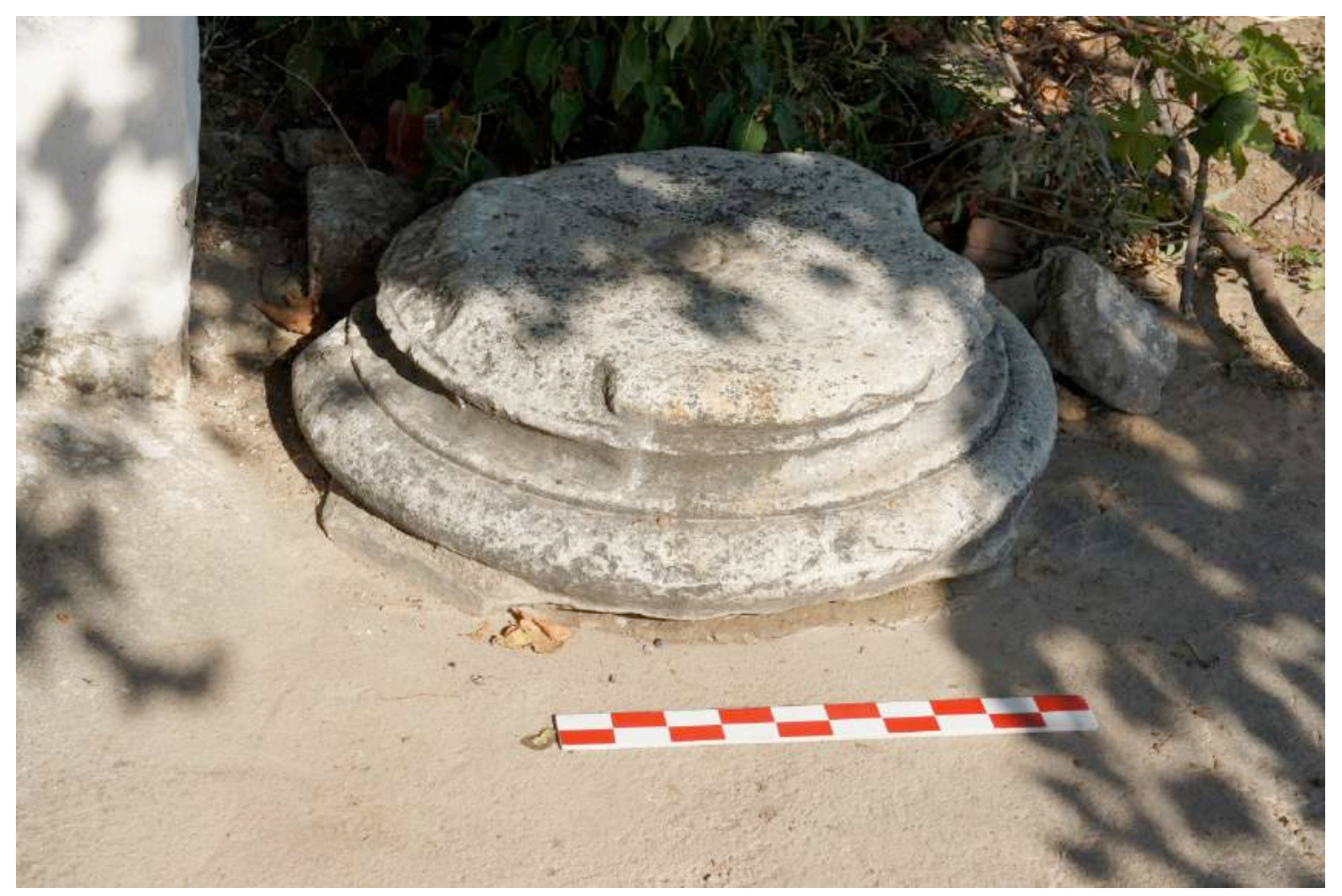

Fig. 9 


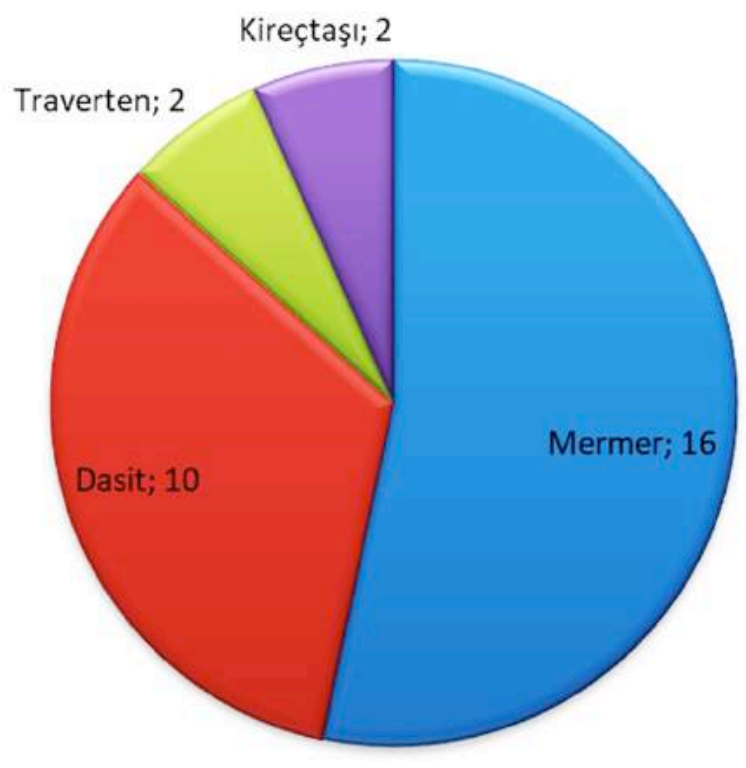

Fig. 10

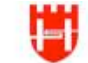

HISTORY

STUDIES

1940

Volume 11

Issue 6

December

2019

Fig. 11 
Aydın Erön

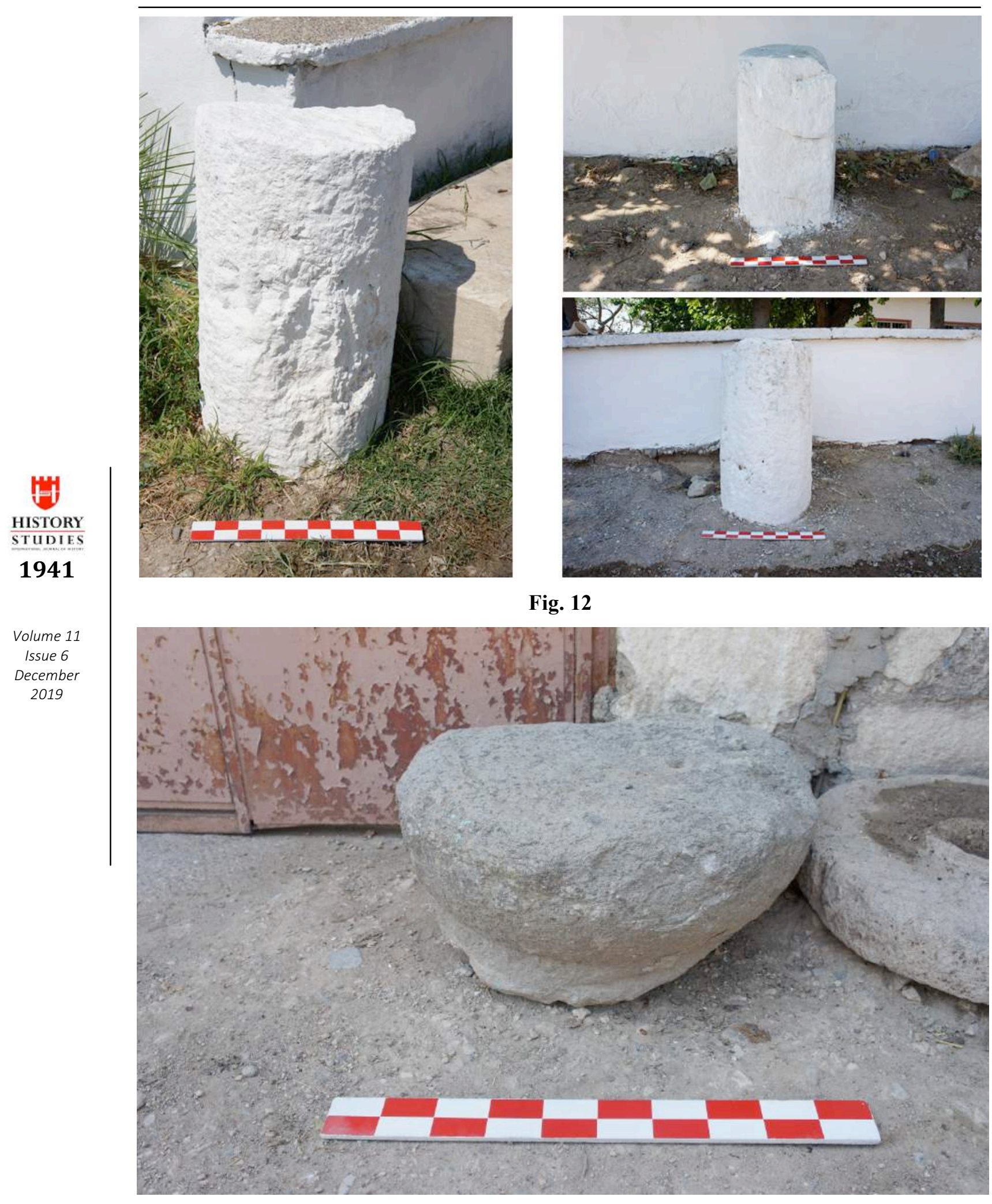

Fig. 13 
Devşirme Mimari Malzeme Kullanımı Üzerine Düșünceler

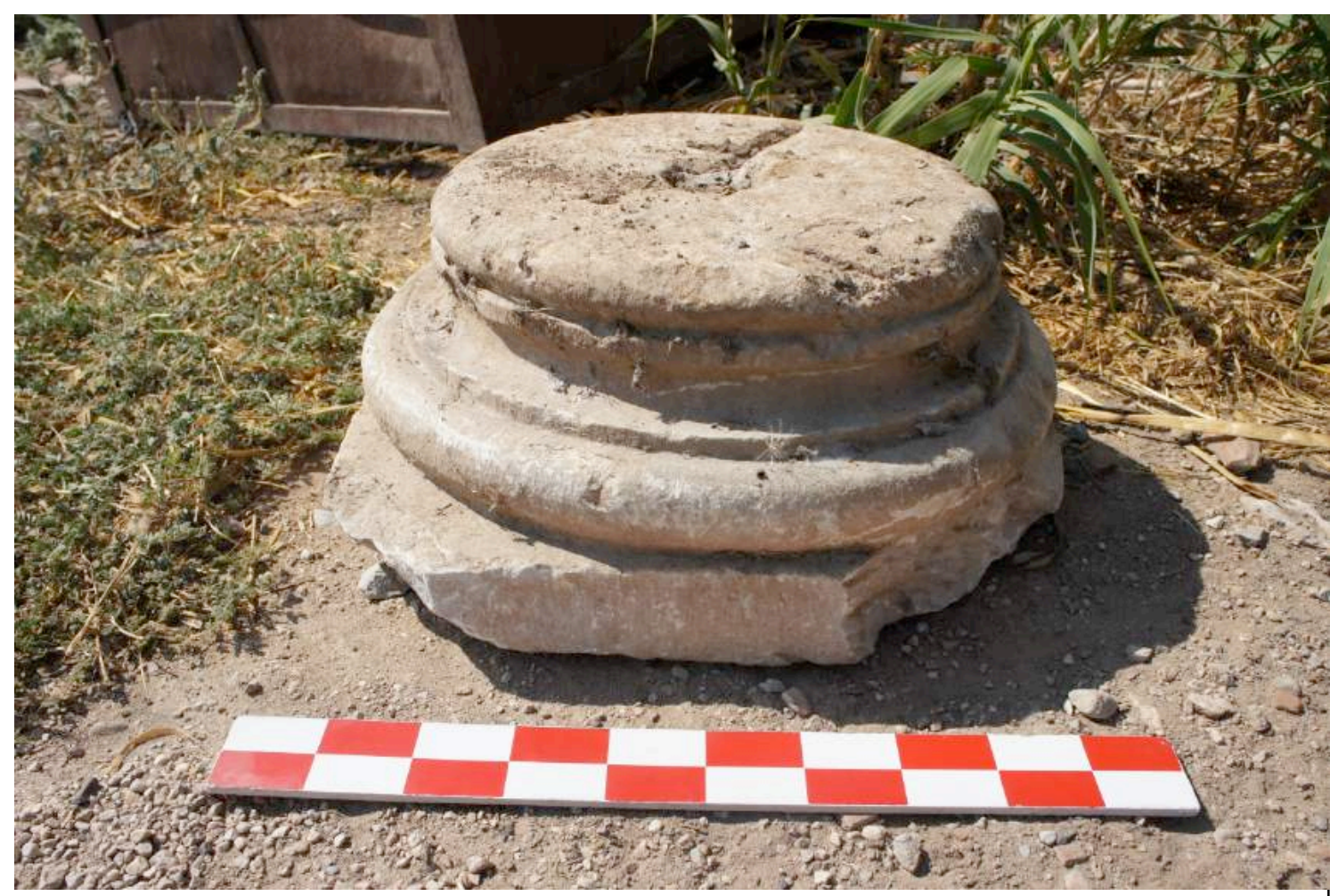

Fig. 14

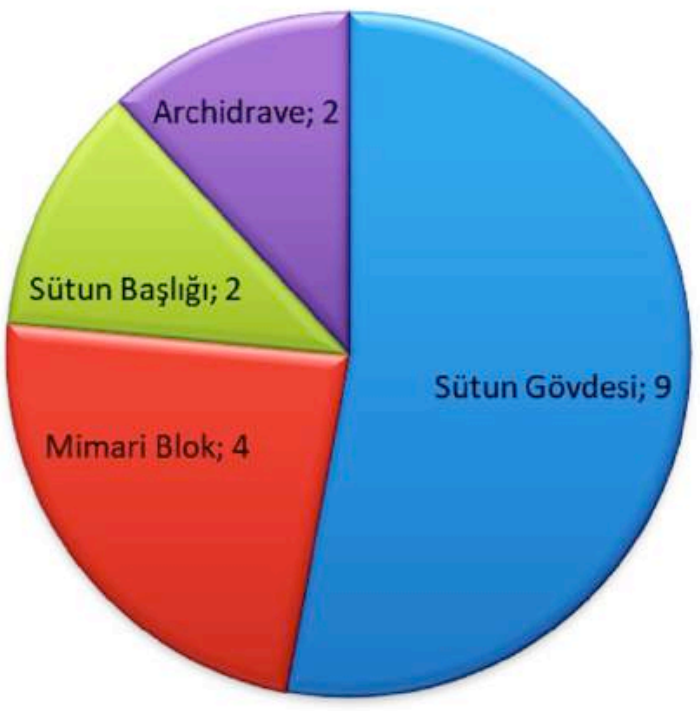

2019

Fig. 15 

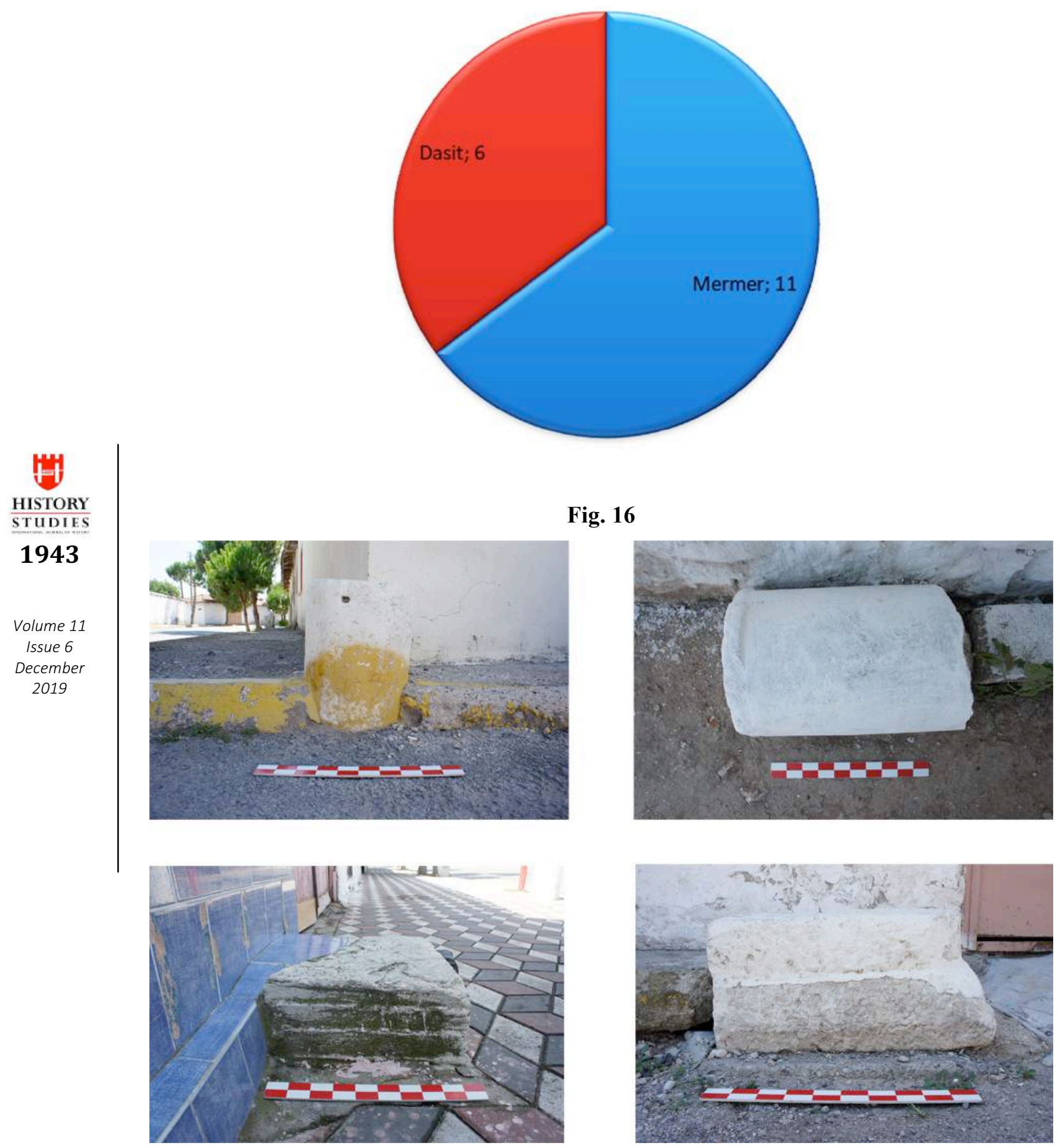

Fig. 17 
Devşirme Mimari Malzeme Kullanımı Üzerine Düşünceler

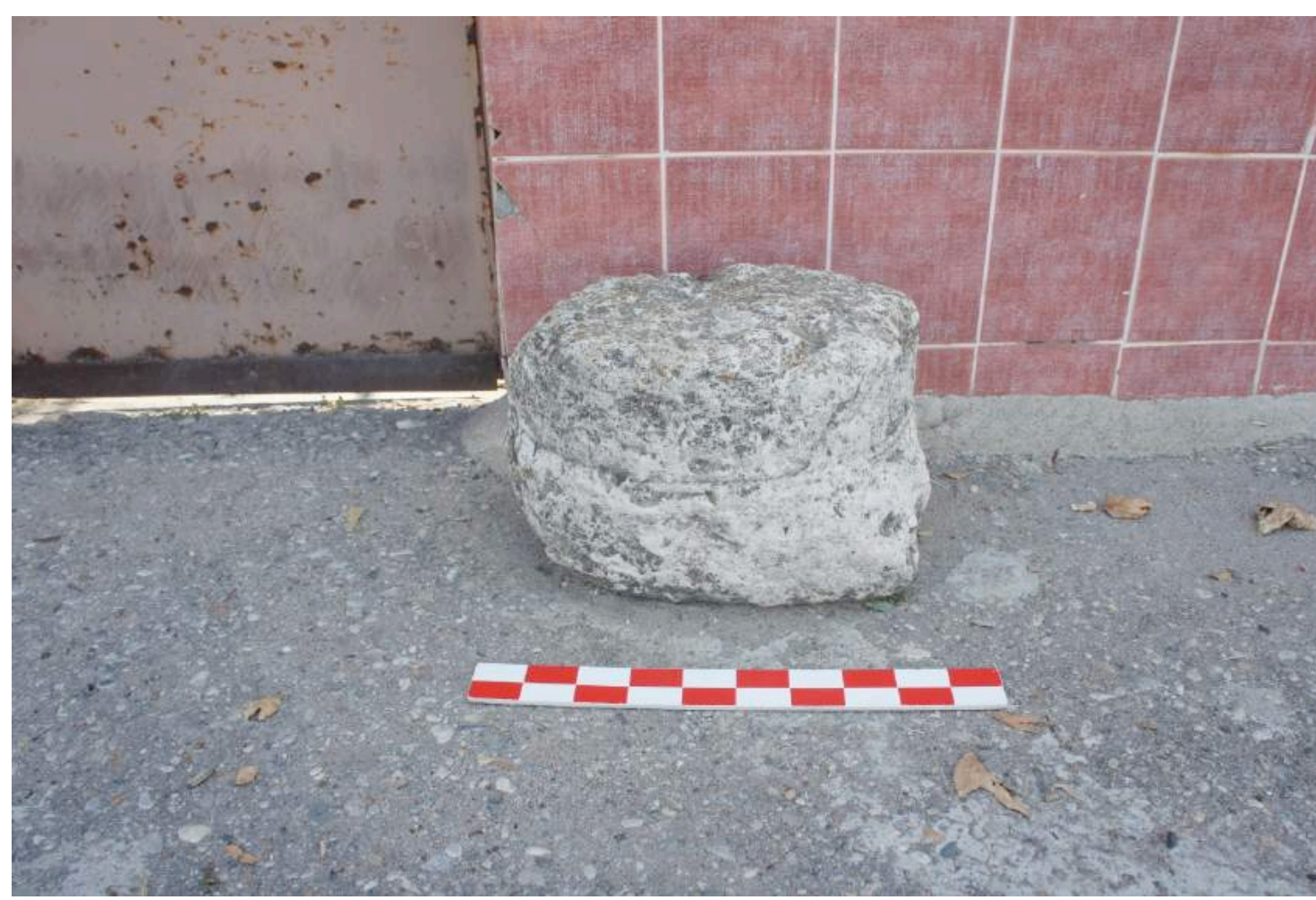

Fig. 18

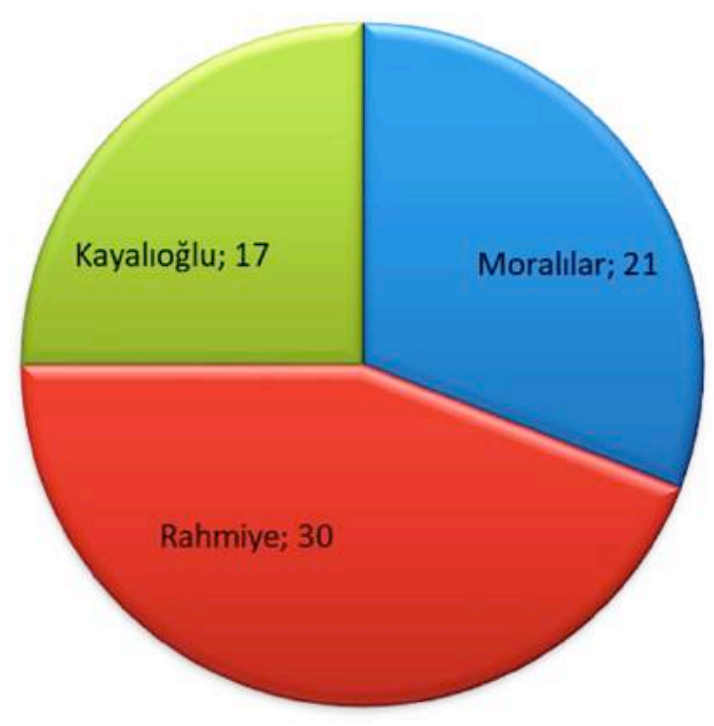

Fig. 19 


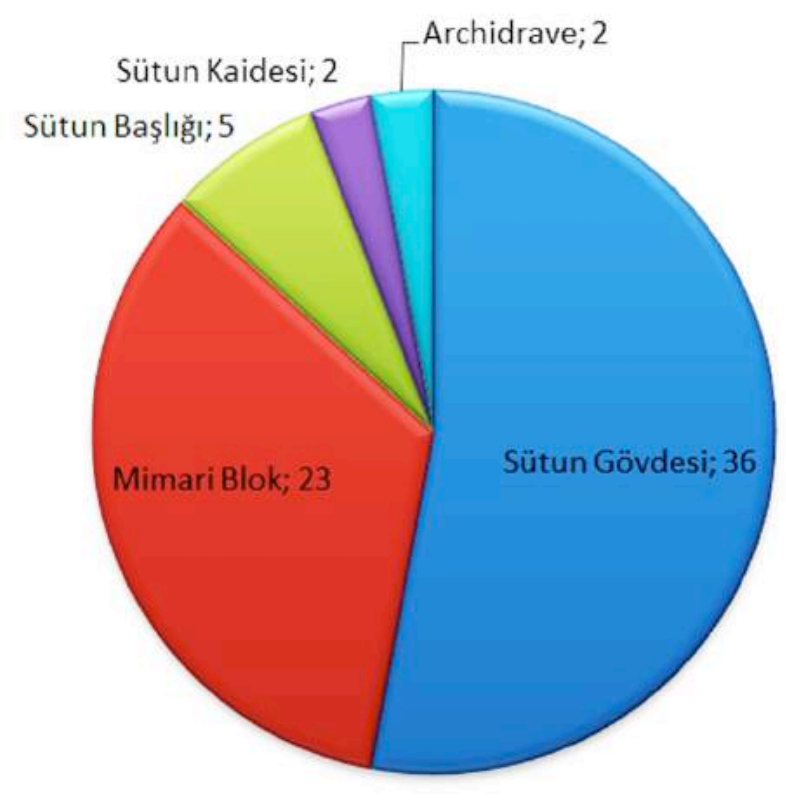

Fig. 20

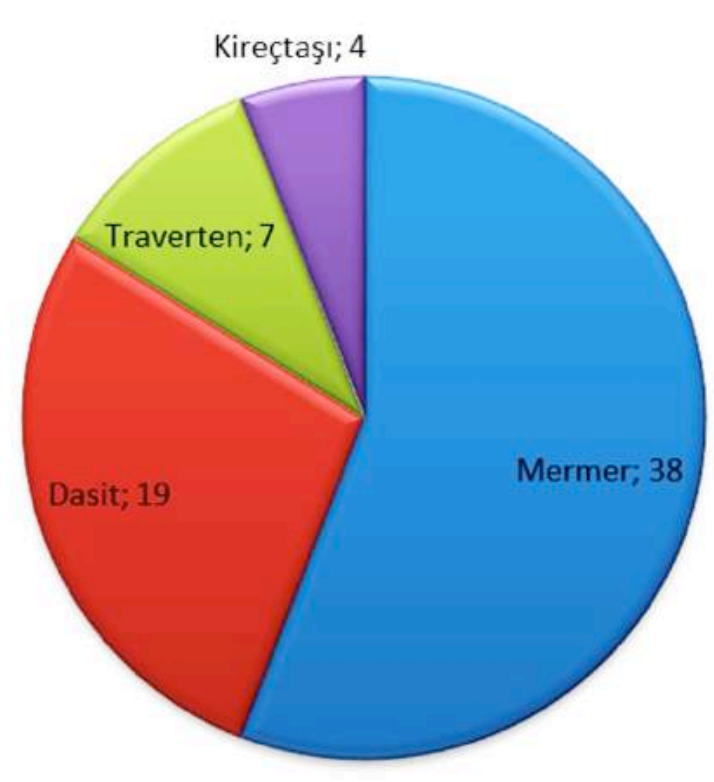

Fig. 21 